Jurnal Ilmiah Kesehatan Sandi Husada
https://akper-sandikarsa.e-journal.id/JIKSH
Volume 10| Nomor 2| Desember|2021
e-ISSN: 2654-4563 dan p-ISSN: 2354-6093
DOI 10.35816/jiskh.v10i2.617

\title{
Literature Review \\ Pengaruh Daun Salam (Syzygium polyanthum) Terhadap Kadar Trigliserida dan Kolesterol Total Darah Pada Penderita Dislipidemia
}

\author{
Lovina Ramadhita Agung ${ }^{1}$ \\ ${ }^{1}$ Fakultas Kedokteran, Universitas Lampung
}

\section{Article Info}

Abstract

Article History:
Received
2021-06-01
Accepted
2021-08-31
Published
2021-12-31

Key words:
Daun salam;
Kadar Trigliserida;
Kolesterol Total Darah;
Dislipidemia;

Pendahuluan: Dislipidemia dihasilkan dari abnormalitas pada metabolisme lipid atau transportasi lipid plasma atau gangguan dalam sintesis dan degradasi lipoprotein plasma. Tujuan: mengetahui pengaruh ekstrak daun salam (Syzygium polyanthum) terhadap kadar trigliserida dan kolesterol total darah. Metode: Menggunakan studi literatur dari jurnal baik nasional maupun internasional dengan cara meringkas topik pembahasan dan membandingkan hasil yang disajikan dalam setiap artikel. Hasil: Dibalik kemanfaatannya yang berguna untuk kesehatan, daun salam sangat mudah ditemukan di Indonesia. Penurunan kadar kolesterol dengan pemberian ekstrak daun salam dapat terjadi karena daun salam (S. polyanthum) mengandung flavonoid yang salah satunya ada senyawa quersetin. Quersetin dapat menghambat oksidasi LDL yang telah dimodifikasi makrofag, yaitu dengan mengurangi kandungan $\alpha$-tocopherol yang terkandung dalam partikel LDL. Flavanoid juga bekerja dengan cara menghambat enzim HMG-CoAReduktase sehingga sintesis kolesterol menurun mengakibatkan kadar kolesterol darah menurun. Kesimpulan: pemberian daun salam dapat menurunkan kadar trigliserida dan kolesterol total darah yang berlebih.

Introduction: Dyslipidemia results from abnormalities in lipid metabolism or plasma lipid transport or disturbances in the synthesis and degradation of plasma lipoproteins characterized by an increase or decrease in the lipid fraction in plasma. Objective: To determine the effect of bay leaf extract (Syzygium polyanthum) on triglyceride and total blood cholesterol levels. Methods: Using literature studies from both national and international journals by summarizing the discussion topics and comparing the results presented in each article. Result: Behind its health benefits, bay leaves are very easy to find in Indonesia. The decrease in cholesterol levels by giving bay leaf extract can occur because bay leaves (S. polyanthum) contain flavonoids, one of which is quercetin. Quercetin can inhibit the oxidation of LDL that has been modified by macrophages, namely by reducing the content of to-tocopherol contained in LDL particles. Flavonoids also work by inhibiting the HMG-CoA Reductase enzyme so that cholesterol synthesis decreases resulting in decreased blood cholesterol levels. Conclusion: giving bay leaves can reduce excessive triglyceride and total blood cholesterol levels.

$\begin{array}{ll}\text { Corresponding author } & \text { : Lovina Ramadhita Agung } \\ \text { Email } & \text { : lovinaagung.la@gmail.com }\end{array}$

\section{Pendahuluan}

Dislipidemia merupakan salah satu masalah kesehatan di Indonesia. Dislipidemia dihasilkan dari abnormalitas pada metabolisme lipid atau transportasi lipid plasma atau gangguan dalam sintesis dan degradasi lipoprotein plasma dan merupakan kelainan metabolisme lipid yang ditandai dengan peningkatan atau penurunan fraksi lipid dalam plasma. Kelainan fraksi lipid yang utama adalah kenaikan kadar kolesterol total, Low-Density Lipoprotein (LDL), dan trigliserida, serta penurunan kadar High-Density Lipoprotein (HDL) (Farahdina, 2015). Terdapat 2 macam dislipidemia yaitu dyslipidemia primer, yaitu dislipidemia yang disebabkan karena kelainan penyakit genetik dan bawaan yang dapat menyebabkan kelainan kadar lipid dalam darah. Dan dislipidemia Sekunder, yaitu dislipidemia yang disebabkan oleh suatu keadaan seperti hiperkolesterolemia yang diakibatkan oleh hipotiroidisme, syndrome nefrotik, kehamilan, 
anoreksia nervosa, dan penyakit hati obstruktif. Dan hipertrigliserida disebabkan oleh diabetes mellitus, konsumsi alkohol, gagal ginjal kronik, miokard infark, dan kehamilan (Sharma \& Singh, 2012).

American Heart Association diperkirakan bahwa saat ini terdapat 98 juta warga Amerika mempunyai kadar kolesterol lebih dari $200 \mathrm{mg} / \mathrm{dl}$ dan diperkirakan akan terus meningkat. Dislipidemia merupakan faktor resiko primer utuk penyakit jantung koroner dan berperan sebelum faktor resiko utama lainnya muncul. Data epidemiologi menunjukkan bahwa setiap penurunan LDL sebesar 5-30 mg/dL maka akan terjadi penurunan resiko untuk penyakit jantung koroner sebesar $30 \%$. Asupan asam lemak jenuh yang dianjurkan untuk memenuhi kebutuhan dalam tubuh adalah $10 \%$ dari energi total perhari dan kolesterol $>300 \mathrm{mg} / \mathrm{hari}$. Konsumsi asam lemak dapat meningkatkan kadar kolesterol LDL. Kejadian jika kolesterol LDL meningkat serta HDL menurun, akan terjadi penimbunan kolesterol di jaringan perifer termasuk pembuluh darah (Sanggih et al., 2019). Untuk menurunkan kadar kolesterol dalam darah dapat dilakukan terapi farmakologis maupun terapi non farmakologis (anwar, 2012). Pada saat ini dikenal sedikitnya 6 jenis obat yang dapat memperbaiki profil lipid serum yaitu bile acid sequestran, HMG-CoA reductase inhibitor (statin), derivate asam fibrat, asam nikotinik, ezetimebe dan asam lemak omega-3. Diingatkan lagi selain obat tersebut, pada saat ini telah dipasarkan obat kombinasi dua jenis penurun lipid dalam satu tablet seperti Advicor (lofastatin dan niaspan), Vytorin (simvastatin dan ezetimebe). Berdasarkan penelitian yang ada, obat-obatan herbal telah dilaporkan efektif dalam pengobatan dislipidemia dan pencegahan penyakit kardiovaskular (Zeng, 2012). Dimasa kini masyarakat mulai mencari berbagai obat-obat alternative. Masyarakat mulai menggunakan bahan-bahan alami, salah satunya adalah tanaman salam (Feng et al., 2010). Daun salam (sygium polyanthum) adalah tanaman yang bisa di manfaatkan daunnya buat penyedap rasa pada masakan khas nusantara, tidak hanya itu daunnya juga pula bisa digunakan bagaikan rempah penyembuhan tradisional Indonesia bay-leaf atau indonesia laurel, sedangkan nama ilmiah dari daun salam adalah sygium polyanthum (Nova Arikhman, 2021)Daun salam atau dengan nama lain yaitu syzygium polyanthum adalah daun yang selalu ada hampir di dalam masakan warga indonesia. Tidak hanya bagaikan bumbu masakan, daun salam pula sesungguhnya mempunyai banyak manfaat serta khasiat yang lain untuk kesehatan badan kita. Daun salam dipercaya bisa digunakan bagaikan obat-obatan herbal buat penyakit kolesterol, diabet, asam urat, serta radang lambung (Agustin, 2020). Berdasarkan uraian permasalahan tersebut, peneliti bermaksud melakukan tinjauan literatur yang bertujuan untuk mengetahui pengaruh ekstrak daun salam (Syzygium polyanthum) terhadap kadar trigliserida dan kolesterol total darah.

\section{Metode}

Metode yang digunakan oleh penulis adalah studi literatur dari berbagai sumber yang berjumlah lebih dari 20 sumber, dari jurnal nasional maupun internasional. Studi literatur ini dilakukan dengan cara membaca, memahami, dan mereview literatur dari berbagai macam sumber. Metode ini digunakan dengan tujuan menyajikan, menambah pengetahuan dan pemahaman mengenai topik yang dibahas dengan meringkas materi yang telah diterbitkan serta memberikan informasi fakta atau analisis baru dari tinjauan literatur yang relevan kemudian membandingkan hasil tersebut dalam artikel.

\section{Hasil Dan Pembahasan}

Dislipidemia merupakan gangguan umum yang disebabkan oleh kebiasaan gaya hidup di negara-negara maju dan berkembang dan merupakan penyebab utama penyakit jantung koroner. Dislipidemia dihasilkan dari abnormalitas pada metabolisme lipid atau transportasi lipid plasma atau gangguan dalam sintesis dan degradasi lipoprotein plasma (Li et al., 2015). ditandai dengan peningkatan konsentrasi kolesterol total, kolesterol Low-Density Lipoprotein (LDL), atau trigliserida, dan/atau penurunan kolesterol High-Density Lipoprotein (HDL) (Sahebkar, 2013). Dislipidemia dapat menyebabkan aterosklerosis yang dapat menyebabkan penyakit jantung coroner dan stroke. Dengan demikian dislipidemia meningkatkan risiko terjadinya penyakit jantung koroner dan stroke (Kim et al., 2014). Kadar kolesterol serum dan trigliserida yang tinggi dapat menyebabkan pembentukan arteriosklerosis. Kolesterol dan trigliserida di dalam darah 
terbungkus di dalam protein pengangkut lemak yang disebut lipoprotein. LDL dan very lowdensity lipoprotein (VLDL) membawa lemak ke sel tubuh, termasuk sel endotel arteri. Oksidasi kolesterol dan trigliserida menyebabkan pembentukan radikal bebas yang diketahui merusak sel-sel endotel. Kadar trigliserida di atas $200 \mathrm{mg} / \mathrm{dl}$ perlu diwaspadai dan perlu dikendalikan (Tandra, 2021). Menurut (Brown \& Grundy, 2014) menunjukkan bahwa untuk setiap penurunan LDL sebesar $30 \mathrm{mg} / \mathrm{dL}$ maka akan terjadi penurunan risiko relatif untuk penyakit jantung koroner sebesar 30\%. Data di Indonesia yang diambil dari riset kesehatan dasar nasional (RISKESDAS) tahun 2013 menunjukkan ada 35.9\% dari penduduk Indonesia yang berusia $\geq 15$ tahun dengan kadar kolesterol abnormal (berdasarkan NCEP ATP III, dengan kadar kolesterol $\geq 200 \mathrm{mg} / \mathrm{dl}$ ) dimana perempuan lebih banyak dari laki-laki dan perkotaan lebih banyak dari di pedesaan. Data RISKEDAS juga menunjukkan $15.9 \%$ populasi yang berusia $\geq 15$ tahun mempunyai proporsi LDL yang sangat tinggi ( $\geq 190 \mathrm{mg} / \mathrm{dl}), 22.9 \%$ mempunyai kadar HDL yang kurang dari $40 \mathrm{mg} / \mathrm{dl}$, dan $11.9 \%$ dengan kadar trigliserid yang sangat tinggi ( $\geq 500 \mathrm{mg} / \mathrm{dl}$ ).

Pada usia 10 tahun bercak perlemakan sudah dapat ditemukan di pembuluh darah. Prevalensi hiperkolesterolemia pada kelompok usia 25-34 tahun adalah 9,3\% dan meningkat sesuai dengan pertambahan usia hingga 15,5\% pada kelompok usia 55-64 tahun. Faktor kegemukan/ obesitas salah satu penyebab kolesterol naik, kelebihan berat badan bias disebabkan oleh makanan yang terlalu banyak yang mengandung lemak jahat tinggi di dalamnya. Kelebihan berat badan dapat meningkatkan trigliserida dan dapat menurunkan HDL (Ghani et al., 2016). Berolahraga juga mampu meproduksi enzim yang berperan untuk membantu proses memindahkan kolesterol LDL dalam darah terutama pada pembuluh arteri kemudian dikembalikan menuju ke hati untuk diubah menjadi asam empedu. Asam empedu ini diperlukan melancarkan proses pencernaan kadar lemak dalam darah. Semakin rutin berolahraga dengan teratur maka kadar kolesterol LDL dalam tubuh akan semakin berkurang sampai menuju ke titik normal (Fuadah \& Arisman, 2012). Pola dan gaya hidup yang tidak baik merupakan faktor resiko penyakit jantung. Pola kehidupan manusia di zaman modern yang cenderung serba enak dan hedonis serta aktivitas gerak yang serba minimalis, dapat meningkatkan kadar kolesterol, Low Density Lipoprotein (LDL) dan trigliserida darah (Patmawuri, 2010).Penggunaan obat-obatan sebagai farmakoterapi dari dislipidemia banyak digunakan, salah satunya adalah obat golongan statin yang dapat menghambat dari katabolisme LDL. Obat golongan statin adalah obat yang paling banyak digunakan untuk farmakoterapi dari dislipidemia. Simvastatin adalah salah satu obat golongan statin yang sering digunakan, mekanisme kerjanya dengan cara menghambat HMG-CoA reduktase secara kompetitif pada proses sintesis kolesterol di hati. Simvastatin akan menghambat HMG-CoA reduktase mengubah asetil-CoA menjadi asam mevalonat (Sodipo et al., 2011). Dan simvastatin menginduksi suatu peningkatan reseptor LDL dengan afinitas tinggi. Efek tersebut meningkatkan kecepatan ekstraksi LDL oleh hati, sehingga mengurangi simpanan LDL plasma (Lim, 2019). Efek samping dari pemakaian Simvastatin adalah miopati, gangguan psikis (depresi, ketakutan, kecenderungan bunuh diri) dan kerusakan hati (sirosis), sakit kepala, konstipasi, gangguan penglihatan, anemia. Kontraindikasi pada obat Simvastatin yaitu pada wanita hamil, menyusui, pasien yang mengalami gagal fungsi hati atau pernah mengalami gagal fungsi hati, pasien yang mengalami peningkatan jumlah serum transaminase yang abnormal, pecandu alkohol (Getz \& Campo, 2017). Karna banyaknya efek samping yang dapat ditimbulkan banyak masyarakat yang mulai menggunakan obat-obatan herbal / alami, salah satunya adalah daun salam. Daun salam (sygium polyanthum) adalah tanaman yang bisa di manfaatkan daunnya buat penyedap rasa pada masakan khas nusantara, tidak hanya itu daunnya juga pula bisa digunakan bagaikan rempah penyembuhan tradisional Indonesia bay-leaf atau indonesia laurel, sedangkan nama ilmiah dari daun salam adalah sygium polyanthum (N Arikhman, 2016). Daun salam banyak digunakan oleh masyarakat di Indonesia dikarenakan daun salam mudah didapatkan, terjangkau dan pemanfaatan daun salam yang belum inovasi, biasanya salam hanya digunakan untuk penyedap masakan. Salam merupakan tanaman yang dipercaya oleh sebagian masyarakat berkhasiat untuk menurunkan kadar kolesterol pada penderita dislipidemia. Senyawa yang terkandung dalam daun salam yaitu senyawa eugenol, metil kavikol, sitral, anti jamur, anti 
bakteri, flavonoid, tanin, vitamin A, B kompleks, C, dan minyak atsiri (Purwaningsih, 2013). Berdasarkan penelitian yang telah dilakukan oleh (Nugroho, 2011) didapatkan hasil bahwa Pemberian ekstrak daun salam (S. polyanthum) dapat menurunkan kadar trigliserida darah tikus putih (R. norvegicus). Penurunan trigliserida akibat pemberian daun salam sebanding dengan efek penurunan kadar trigliserida akibat pemberian gemfibrozil. Penelitian lain yang dilakukan oleh (Irmadoly et al., 2014) membuktikan bahwa ekstrak daun salam dapat menurunkan kadar kolesterol total pada tikus pada dosis yang sama yaitu $20 \mathrm{mg} / 200 \mathrm{~g} \mathrm{BB}$ selama 21 hari dengan pemberian satu kali sehari. Menurut (Marbun, 2019) dari 325 orang yang mengalami dislipidemia/peningkatan kolesterol darah, 110 memenuhi kriteria kelayakan penelitian ini seperti mengalami penurunan kadar kolesterolnya setelah mengonsumsi rebusan daun salam. Penurunan kadar kolesterol dengan pemberian ekstrak daun salam dapat terjadi karena daun salam $(S$. polyanthum) mengandung flavonoid yang berfungsi sebagai anti oksidan (Rusmini et al., 2020). Salah satu kandungan flavonoid yang terdapat pada daun salam adalah quersetin. Diduga quersetin dapat menghambat oksidasi LDL yang telah dimodifikasi makrofag, yaitu dengan mengurangi kandungan $\alpha$-tocopherol yang terkandung dalam partikel LDL (Siregar, 2015). Menurut (Prahastuti et al., 2013) juga melaporkan bahwa flavonoid pada daun salam dapat menurunkan kadar kolesterol dimana flavonoid bekerja dengan cara menghambat enzim HMGCoA Reduktase sehingga sintesis kolesterol menurun mengakibatkan kadar kolesterol darah menurun.

\section{Simpulan Dan Saran}

Daun salam (Syzygium polyanthum) mengandung banyak senyawa aktif yang baik untuk kesehatan tubuh seperti, senyawa eugenol, metil kavikol, sitral, anti jamur, anti bakteri, flavonoid, tanin, vitamin A, B kompleks, C, dan minyak atsiri. Sehingga pemberian daun salam dapat menurunkan kadar trigliserida dan kolesterol total darah yang berlebih.

\section{Daftar Rujukan}

Agustin, P. R. Dela. (2020). Pengaruh Rebusan Daun Salam Terhadap Penurunan Kadar Kolesterol Pada Penderita Hiperkolesterolemia. STIKes Insan Cendekia Medika Jombang.

Arikhman, N. (2016). Faktor-Faktor yang Berhubungan dengan Kejadian Tuberkulosis Paru di Puskesmas Lubuk Alung Kabupaten Padang Pariaman. J Kesehat Med Saintika, 7(2), 108113.

Arikhman, Nova. (2021). Tinjauan Sosial, Etika Dan Hukum Surrogate Mother di Indonesia. Jurnal Kesehatan Medika Saintika, 7(2).

Brown, W. V., \& Grundy, S. (2014). From the editor: an interview with Dr. Scott Grundy. Journal of Clinical Lipidology, 8(1), 1-8.

Farahdina, S. (2015). Donor darah dan profil lipid. Jurnal Majority, 4(6), 51-55.

Feng, D., Ohlsson, L., \& Duan, R.-D. (2010). Curcumin inhibits cholesterol uptake in Caco-2 cells by down-regulation of NPC1L1 expression. Lipids in Health and Disease, 9(1), 1-5.

Fuadah, L. L., \& Arisman, A. (2012). The importance of Forensic Auditing to Combat Fraud in Indonesia.

Getz, K. A., \& Campo, R. A. (2017). Trial watch: trends in clinical trial design complexity. Nature Reviews Drug Discovery, 16(5), 307-308.

Ghani, L., Susilawati, M. D., \& Novriani, H. (2016). Faktor risiko dominan penyakit jantung koroner di Indonesia. Buletin Penelitian Kesehatan, 44(3), 153-164.

Irmadoly, N., Wirajaya, F., Chalista, S., Fam, F. I., \& Se, H. S. (2014). Uji Aktivitas Antidislipidemia In Vivo Fraksi Ekstrak Daun Salam (Eugenia polyantha) pada Tikus Galur Wistar yang diinduksi Diet Tinggi Lemak. Jurnal Kedokteran Dan Kesehatan: Publikasi Ilmiah Fakultas Kedokteran Universitas Sriwijaya, 1(1), 21-23.

Kim, M.-B., Kim, C., Song, Y., \& Hwang, J.-K. (2014). Antihyperglycemic and antiinflammatory effects of standardized Curcuma xanthorrhiza Roxb. extract and its active compound xanthorrhizol in high-fat diet-induced obese mice. Evidence-Based Complementary and Alternative Medicine, 2014.

Li, Z.-Y., Ding, L.-L., Li, J.-M., Xu, B.-L., Yang, L., Bi, K.-S., \& Wang, Z.-T. (2015). 1H-NMR 
and MS-based metabolomics study of the intervention effect of curcumin on hyperlipidemia mice induced by the high-fat diet. Plus One, 10(3), e0120950.

Lim, H. (2019). Farmakologi Kardiovaskuler, Mekanisme \& Aplikasi Klinis.

Marbun, R. (2019). Potensi Pare (Momordica charantia L) Sebagai Penurun Kadar Kolesterol Darah. Jurnal Ilmiah Kesehatan Sandi Husada, 8(2 SE-Articles). https://doi.org/10.35816/jiskh.v10i2.147

Nugroho, A. A. (2011). Pengaruh Ekstrak Daun Salam [Syzygium Polyanthum (Wight) Walp] Terhadap Penurunan Kadar Trigliserida Darah Tikus Putih (Rattus Norvegicus).

Patmawuri, Y. A. (2010). Pengaruh pemberian seduhan kelopak rosela (hibiscus sabdariffa) terhadap kadar kolesterol ldl darah tikus putih (rattus norvegicus) dengan induksi hiperkolesterolemi.

Prahastuti, S., Tjahjani, S., \& Hartini, E. (2013). The effect of bay leaf infusion (Syzygium polyanthum (Wight) Walp) to decrease blood total cholesterol level in dyslipidemia model wistar rats. Jurnal Medika Planta, 1(4).

Purwaningsih, E. H. (2013). Jamu, obat tradisional asli Indonesia: pasang surut pemanfaatannya di Indonesia. EJournal Kedokteran Indonesia, 85-89.

Rusmini, H., Putri, D., Hidayat, H., \& Risandy, D. (2020). Pengaruh Madu Ceiba Pentandra Terhadap Kadar LDL Tikus Rattus Norvegicus Yang Diberi Diet Tinggi Lemak. Jurnal Ilmiah Kesehatan Sandi Husada, 9(1 SE-Articles). https://doi.org/10.35816/jiskh.v11i1.331

Sahebkar, A. (2013). Fat lowers fat: purified phospholipids as emerging therapies for dyslipidemia. Biochimica et Biophysica Acta (BBA)-Molecular and Cell Biology of Lipids, 1831(4), 887-893.

Sanggih, P. R. A., Wahyudo, R., \& Ginarana, A. (2019). Efek buah nanas (Ananas comosus 1. Merr) terhadap penurunan kadar kolesterol pada penyakit jantung koroner (PJK). Jurnal Kedokteran Universitas Lampung, 3(1), 205-209.

Sharma, B., \& Singh, N. (2012). The salutary effect of NFkB inhibitor and folacin in hyperhomocysteinemia-hyperlipidemia induced vascular dementia. Progress in NeuroPsychopharmacology and Biological Psychiatry, 38(2), 207-215.

Siregar, R. N. I. (2015). The effect of Eugenia polyantha extract on LDL cholesterol. Jurnal Majority, 4(5).

Sodipo, O. A., Abdulrahman, F. I., Sandabe, U. K., \& Akinniyi, J. A. (2011). Drug therapy for hyperlipidemia (dyslipidemia)-A review. J Appl Pharm Sci, 1, 1-6.

Tandra, H. (2021). Kolesterol \& Trigliserida: Strategi Mencegah dan Mengalahkan Serangan Jantung dan Stroke. Gramedia Pustaka Utama. 